\title{
A new set of differentially expressed signaling genes is early expressed in coffee leaf rust race II incompatible interaction
}

\author{
Valdir Diola • Giovani G. Brito • Eveline T. Caixeta • \\ Luiz F. P. Pereira $\cdot$ Marcelo E. Loureiro
}

Received: 18 November 2012 / Revised: 11 June 2013 / Accepted: 25 June 2013 / Published online: 9 July 2013

(C) Springer-Verlag Berlin Heidelberg 2013

\begin{abstract}
New races of coffee rust are overcoming resistance genes available in germplasm and cultivated cultivars and bringing recently some coffee-producing countries in severe economic challenge. The objective of this study was to identify the genes that are linked to host resistance to the major coffee rust race II. In our study, we have identified and studied a segregating population that has a single monogenic resistant gene to coffee rust. Coffee leaves of parents, resistant, and susceptible genotypes of the $\mathrm{F}_{2}$ generation plants were inoculated with pathogen spores. A differential analysis was performed by combined cDNA-AFLP and bulk segregant analysis (BSA) in pooled samples collected 48 and $72 \mathrm{~h}$ postinoculation, increasing the selectiveness for differential gene expression. Of 108 differential expressed genes, between 33,000 gene fragments analyzed, 108 differential expressed
\end{abstract}

Electronic supplementary material The online version of this article (doi:10.1007/s10142-013-0330-7) contains supplementary material, which is available to authorized users.

\author{
V. Diola $(\bowtie)$ \\ Departamento de Biologia Vegetal, Universidade Federal de \\ Viçosa, Viçosa, MG, Brazil \\ e-mail: valdirdiola@ufrrj.br \\ G. G. Brito \\ EMBRAPA Algodão, Núcleo Cerrado, Goiânia, GO, Brazil \\ E. T. Caixeta \\ EMBRAPA Café/Bioagro, Brasília, DF, Brazil \\ L. F. P. Pereira \\ EMBRAPA Café/Londrina, Londrina, PR, Brazil
}

M. E. Loureiro

Departamento de Biologia Vegetal, Universidade Federal de Viçosa, Viçosa, MG, Brazil

Present Address:

V. Diola

Departamento de Genética, Universidade Federal Rural do Rio de Janeiro, Seropédica, RJ, Brazil genes were identified in resistant plants. About 20 and $22 \%$ of these resistant-correlated genes are related to signaling and defense genes, respectively. Between signaling genes, the major subclass corresponds to receptor and resistant homolog genes, like nucleotide-binding site leucine-rich repeat (NBS$L R R$ ), Pto-like, RLKs, Bger, and RGH1A, all not previously described in coffee rust responses. The second major subclass included kinases, where two mitogen-activated kinases (MAPK) are identified. Further gene expression analysis was performed for 21 selected genes by real-time PCR gene expression analysis at $0,12,24,48$, and $72 \mathrm{~h}$ postinoculation. The expression of genes involved in signaling and defense was higher at 24 and $72 \mathrm{~h}$ after inoculation, respectively. The $N B S-L R R$ was the more differentially expressed gene between the signaling genes (four times more expressed in the resistant genotype), and thraumatin (PR5) was the more expressed between all genes (six times more expressed). Multivariate analysis reinforces the significance of the temporal separation of identified signaling and defense genes: early expression of signaling genes support the hypothesis that higher expression of the signaling components up regulates the defense genes identified. Additionally the increased gene expression of these two gene sets is associated with a single monogenic resistance trait to to leaf coffee rust in the interaction characterized here.

Keywords Hemileia vastatrix · Host-specific resistance . R-genes · Transcript-derived fragments · Defense response · Signaling in response to pathogens

\section{Introduction}

Coffee leaf rust, which is caused by the biotrophic fungus Hemileia vastatrix, is the major disease of coffee with losses in production that may range from 35 to $50 \%$, if not properly controlled (Zambolim et al. 2002). H. vastatrix is considered one of the most ancient rust lineages (Grasso et al. 2006), and 
resistance of coffee involve some strategies as old as the occurrence of rust, making this system one important research field to be explored about coevolution of pathogenhost genomes. As an example, in coffee rust incompatible interactions, hypersensitive reaction can occur as early as at the appressorial stage, making this a unique feature among rusts (Silva et al. 2008). The hypersensitive response (HR) is expressed by death of guard and subsidiary cells in stomata, so early as the fungus developed an appressorium (Siva et al. 2006). The resistance to this disease is is expressed by a rapid hypersensitive cell death at leaf infection sites (Rodrigues et al. 1975; Silva et al. 2006). In resistant coffee plants, fungus growth usually terminates after formation of the first haustoria in mesophyll cells (Silva et al. 2006). The use of resistant cultivars has been the most efficacious strategy to control this disease. However, the coffee pathosystem includes 45 pathogenic races of $H$. vastatrix in the world (Várzea and Marques 2005). In Brazil, a previous study differentiated 14 race I, but race II is the most widely distributed (Cabral et al. 2009). In our Hibrid de Timor germplasm, derived from seed brought from Timor Island, this resistance was defined as monogenic (Brito et al. 2010) or polygenic (Capucho et al. 2009) depending of plant genotype. In coffee leaf, rust racespecific resistance appears to be determined by at least nine genetic factors (called $\mathrm{S}_{\mathrm{H}} 1$ to $\mathrm{S}_{\mathrm{H}}$ 9), alone or in combination, and virulence is determined by factors $\mathrm{v} 1$ to $\mathrm{v} 9$ (Bettencourt and Rodrigues 1988). The resistance factors $\mathrm{S}_{\mathrm{H}} 1, \mathrm{~S}_{\mathrm{H}} 2, \mathrm{~S}_{\mathrm{H}} 4$, and $\mathrm{S}_{\mathrm{H}} 5$ were identified in the germplasm of $C$. arabica (Rodrigues et al. 1975). The other factors were introgressed from other species, including $\mathrm{S}_{\mathrm{H}} 6, \mathrm{~S}_{\mathrm{H}} 7, \mathrm{~S}_{\mathrm{H}} 8$, and $\mathrm{S}_{\mathrm{H}} 9$ from $C$. canephora (Rodrigues et al. 1975) and $\mathrm{S}_{\mathrm{H}} 3$ from C. liberica (Prakash et al. 2004). Besides these, at least two resistance genes not yet characterized were detected. The Híbrido de Timor (HT) germplasm is the main source of resistance to $H$. vastatrix. These plants originated from the spontaneous cross between $C$. arabica and $C$. canephora. The HT germplasm has at least five dominant genes $\left(\mathrm{S}_{\mathrm{H}} 5, \mathrm{~S}_{\mathrm{H}} 6, \mathrm{~S}_{\mathrm{H}} 7, \mathrm{~S}_{\mathrm{H}} 8\right.$, and $\mathrm{S}_{\mathrm{H}} 9$ ) that can differ between HT derivatives. The HT CIFC $832 / 1$ has the five genes and other HT derivatives, as the Catimor group have $\mathrm{S}_{\mathrm{H}}(5,6,7$, and 9$), \mathrm{S}_{\mathrm{H}} 5,8, \mathrm{~S}_{\mathrm{H}}(5,6$, and 9), $S_{H} 6$, and $S_{H} 5$ (Bettencourt et al. 1992). The Brazilian germplasm has a collection of HT, which contains important sources of gene for disease resistance. The HT UFV 427-15, which belongs to this germplasm, was previously study by Brito et al. (2010) and Diola et al. (2011). They found that the resistance of this HT to race II of $H$. vastatrix was determined by one dominant gene that is still unknown. The information about the inheritance of the vertical resistance of coffee is significant; however, the characterization of the genetic factor and the mode of signaling and defense response are needed to understand the mechanisms of evolution breaks of resistance and overcoming virulence. Studies aiming to understand the complex interaction of coffee and $H$. vastatrix are important to increase the knowledge of the resistance and to get efficient control of this disease. In general, when the pathogen infects the plants, they are able to protect themselves against pathogens by the induction of highly sophisticated and usually complex defense mechanisms (Li et al. 2010).

Guzzo et al. (2009) have produced subtracted cDNA libraries and sequenced genes distributed in induced genes by acibenzolar-S-methyl (ASM) in a susceptible cultivar and in an incompatible interaction (HT 831/H. vastatrix race II). In this last class, the authors have gotten definitive evidences by real-time PCR of eight resistance-associated genes, including a glucanase, $\mathrm{ABC}$ transporter, lipoxygenase, and an NBS-LRR resistance gene. Ramiro et al. (2010) had characterized several members of WRKY transcription factors. Diniz et al. (2012) has compared host (race II) and nonhost rust (Uromyces vignea) using HT 832-2 and has characterized the gene expression of 11 genes by real-time PCR, previously selected as potentially involved in rust response. The reported cellular and molecular resistance responses of HT 832/2 to these rust fungi were interpreted by the authors as if common immunity components are shared between host and nonhost resistance. Ramiro et al. (2010) have used a different incompatible coffee leaf interaction $(C$. arabica var. Caturra/race VI) and identified 10 WRKY transcription factors that are induced in the Caturra genotype, which were not reported in the compatible interaction (C. arabica var. Tupy/race II).

In a compatible interaction, this process occurs $12 \mathrm{~h}$ after inoculation (Vieira et al. 2012). In resistant varieties, a sequence of molecular signals at the plasmatic membrane is required to control fungal development (You-Xiong et al. 2008). Effective pathogen recognition, which is triggered by conserved pathogen elicitors (Duplessis et al. 2011), is the first step towards resistance; this broad-range immunity is mediated by high-affinity plant cell surface receptors (Nishimura and Dangl 2010). During the process of fungus recognition, genes belonging to the nucleotide-binding site leucine-rich repeat (NBS-LRR) class (R-genes, Duplessis et al. 2011), which coffee gene family was characterized by Noir et al. (2001) play important roles in the activation of resistance via a signaling cascade (Ganesh et al. 2006). Rgenes contain highly conserved structural domains (NBSs) and hypervariable domains (LRRs) (Leng et al. 2010); the functions of these domains include recognition of the pathogenic elicitors and activation of defense response proteins, the pathogenesis-related proteins (PRs) (Li et al. 2010), and a series of other proteins (Guzzo et al. 2009; Vieira et al. 2012).

The cultivation of large areas with coffee offers a special environment for rapid coffee rust evolution, and recently, new races with large numbers of susceptible phenotypes in Brazil have been detected (Cabral et al 2009). In fact, at the end of 2012, three countries have declared state of emergence due to the uncommon losses caused by coffee leaf rust 
(Cressy 2013) and the recently reported breakdown of HDT832/1 and HDT832/2 resistance in an Indian germplasm bank (Prakash et al. 2010) illustrates this quick evolution and great genetic variability of $\mathrm{H}$. vastatrix populations. Taking in account that an average of 10 years are needed to breed a new coffee variety, detailed molecular characterization of plant responses to incompatible rust races represents an urgent need for the understating of coffee resistance to leaf rust. This effort could be very useful to help breeders in the challenge of the development of resistant cultivars to the new races arising nowadays. Therefore, the purpose of this study was to identify genes involved in host-specific resistance that are activated during the incompatible interaction between coffee plants and $H$. vastatrix race II pathotype. Here, we identified a new set of 108 genes related to resistance of HT using cDNA-AFLP coupled to BSA strategy and detailed temporal analysis of 21 of these genes by real-time PCR to demonstrate that signaling and defense temporal profile expressions are distinct.

\section{Materials and methods}

Plant material and fungus inoculation

The resistant parent Híbrido de Timor UFV 427-15, the susceptible parent Catuaí Amarelo UFV 2143-236 (IAC 30), and a population of $224 \mathrm{~F}_{2}$ plants were characterized for resistance to $H$. vastatrix. The pathotype used was a race II, characterized in a series of differentiating coffee tree clones as described by Cardoso (1986) and has been maintained in the mycology collection of UFV. Leaf discs with diameters of $2.5 \mathrm{~cm}$, obtained from completely developed young leaves from each plant, were placed in germination boxes (plastic box $11 \times 11 \times 3 \mathrm{~cm}$ ) containing moistened foam and nylon. The leaf discs were then inoculated by applying ten $5.0-\mu \mathrm{L}$ drops of uredinospores in distilled water $\left(2.0 \mathrm{mg} \mathrm{mL}^{-1}\right)$ over the abaxial surface of each leaf disc. Phenotyping was performed using two replicates of eight leaves from one plant (Fig. 1a). Uredinospore germination was induced in the dark for $24 \mathrm{~h}$, followed by a photoperiod of $12 \mathrm{~h}$ at $22{ }^{\circ} \mathrm{C}( \pm 2)$. The disease evaluation was performed at 18, 24, and 36 days, taking into account the presence and absence of uredinospores (Fig. 1). To comprise the different groups, five $F_{2}$-resistant and five susceptible genotypes were selected. A new inoculation was performed in these genotypes, and samples were collected at 0, 12, 24, 48, and $72 \mathrm{~h}$ postinoculation for real-time PCR analysis and at 48 and $72 \mathrm{~h}$ for complement DNA-amplified fragment-length polymorphism (cDNA-AFLP). The germination and grower of the $H$. vastatrix were monitored with a stereomicroscope $(10 \times$ magnification).
RNA extraction, and cDNA and double-stranded DNA syntheses

Total RNA was extracted using Concert ${ }^{\mathrm{TM}}$ Plant RNA Reagent (Invitrogen, Carlsbad, CA, USA) following the manufacturer's recommendations. Total RNA was quantified in a spectrophotometer adjusting the concentrations to $300 \mathrm{ng} \mu \mathrm{L}^{-1}$. The physical integrity of the RNA was evaluated by $1 \%$ agarose gel electrophoresis.

To remove contaminating DNA, total RNA was treated with DNase I (RQ-DNase I, Promega, Madison, WI, USA) at a concentration of $1 \mathrm{U}$ of DNase I per microgram of total RNA. The samples for cDNA-AFLP included $4 \mu \mathrm{g}$ of total RNA for each genotype and $1 \mu \mathrm{g}$ for qRT-PCR. cDNA was synthesized using the SuperScript II kit (Invitrogen) with the indicated concentration and volume adjustments (1 reaction $=1 \mu \mathrm{g}$ of total RNA). Two control samples (without reverse transcriptase) were included. Synthesis was validated by amplification with a primer for the coffee plant ubiquitin gene, and the product was visualized by $1 \%$ agarose gel electrophoresis.

The double-stranded DNA (dsDNA) was synthesized according to a modified protocol proposed by D'Alessio and Gerard (1988). For every $80 \mu \mathrm{L}$ of cDNA reaction for each genotype, 4.0 U of RNase H (Promega, Madison, WI, USA), Second-Strand enzyme buffer (Invitrogen, Carlsbad, CA, USA), $0.25 \mathrm{mM}$ of each dNTP, $0.5 \mathrm{mM}$ of DTT, $20 \mathrm{U}$ of T4 DNA ligase (Epicentre Biotechnologies, Madison, WI, USA), and $20 \mathrm{U}$ of $E$. coli DNA polymerase I (Promega) were added, and the final reaction volume was adjusted to $240 \mu \mathrm{L}$ with water. The reaction was incubated for $1 \mathrm{~h}$ at $12{ }^{\circ} \mathrm{C}$, followed by $1 \mathrm{~h}$ at $22^{\circ} \mathrm{C}$. Then, total RNA was removed by adding $20 \mathrm{ng}$ of RNase A (Promega) incubating at $37^{\circ} \mathrm{C}$ for $30 \mathrm{~min}$. The samples were purified using the phenol-chloroform method and diluted in $6 \mu \mathrm{L}$ of $1 \times \mathrm{TE}$ buffer.

\section{TDF identification}

Then, $200 \mathrm{ng}$ of dsDNA from each sample was digested with only the restriction enzyme EcoRI (Promega) for $8 \mathrm{~h}$ at $37^{\circ} \mathrm{C}$. The ligation reaction was performed using $50 \mathrm{ng}$ of the adaptor primer dsEcoRI 5' CTAGTAGACTGCGTACC 3', 3 U of T4 DNA ligase (Promega), and $1 \times$ DNA ligase buffer in a final volume of $20 \mu \mathrm{L}$. The ligation reaction was performed overnight at $8^{\circ} \mathrm{C}$. The reactions were then diluted in $1 \times$ TE buffer at a ratio of $1 / 10$ and stored at $-20^{\circ} \mathrm{C}$ until use. The cDNA-AFLP technique was conducted according to the method described by Bachem et al. (1996). Preselective amplification was performed with 50 ng of the EcoRI 5' GACTGCGTACCAATTCN 3' primer. The following reagents were added to obtain a volume of $25 \mu \mathrm{L}: 2.5 \mu \mathrm{L}$ of diluted digestion reaction, PCR buffer $1 \times$, $1.25 \mathrm{mM}$ of $\mathrm{MgCl}_{2}, 0.25 \mathrm{mM}$ of each dNTP (Promega), and $1.5 \mathrm{U}$ of Taq DNA polymerase (Phoneutria, BH, Brazil). The 
Fig. 1 Phenotypic

characterization of coffee plant resistance to the pathotype of race II of $H$. vastatrix. a Phenotyping replica set containing eight leaf discs from each genotype 24 days after inoculation; resistant (left) and susceptible (right). The presence of spores indicates a complete reproductive cycle and compatible plant-pathogen interaction. b Magnified image of contrasting genotypes
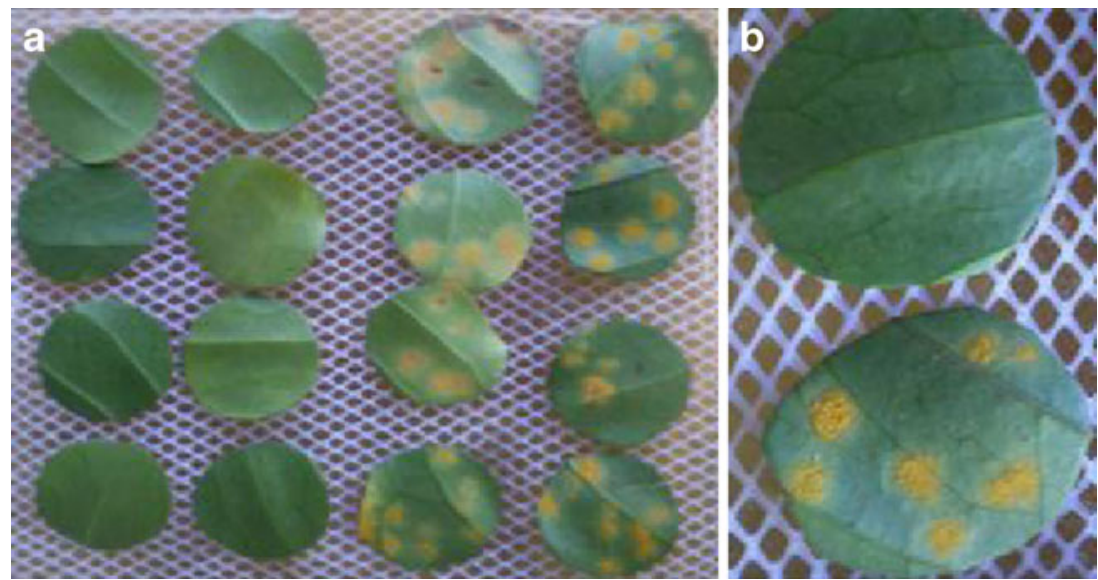

PCR cycling protocol consisted of 24 cycles of $94^{\circ} \mathrm{C}$ for $30 \mathrm{~s}$, $58^{\circ} \mathrm{C}$ for $60 \mathrm{~s}$, and $72{ }^{\circ} \mathrm{C}$ for $60 \mathrm{~s}$. The amplification reactions were diluted $40 \times$. Half of each reaction for the $\mathrm{F}_{2}$ generation genotypes was used to generate the resistant and susceptible genotypes in the systems using bulked analysis segregant (BSA). The other half was used in individual selection reactions and transcript-derived fragment (TDF) confirmation. Selective amplification was performed by touchdown PCR consisting of 13 cycles of $94^{\circ} \mathrm{C}$ for $30 \mathrm{~s}, 65^{\circ} \mathrm{C}\left(-0.7^{\circ} \mathrm{C}\right.$ after each cycle $)$ for $30 \mathrm{~s}$, and $72{ }^{\circ} \mathrm{C}$ for $60 \mathrm{~s}$, followed by 26 cycles of $94{ }^{\circ} \mathrm{C}$ for $30 \mathrm{~s}, 58^{\circ} \mathrm{C}$ for $30 \mathrm{~s}$, and $72{ }^{\circ} \mathrm{C}$ for $60 \mathrm{~s}$ in a volume of $20 \mu \mathrm{L}$ containing $4.0 \mu \mathrm{L}$ of the $40 \times$ dilution of preselective reaction and the following reagents: Taq DNA polymerase buffer $1 \times$, $1.25 \mathrm{mM}$ of $\mathrm{MgCl}_{2}, 0.25 \mathrm{mM}$ of each dNTP (Promega), $50 \mathrm{ng}$ of each selective primer, and $1.5 \mathrm{U}$ of Taq DNA polymerase (Phoneutria). The reaction products were separated by $6 \%$ denaturing polyacrylamide gel electrophoresis (19:1) at
$1,800 \mathrm{~V}$ for $2.5 \mathrm{~h}$, and silver nitrate staining was performed as described by Brito et al. (2010). After drying, an image of the gel was digitally captured and used to analyze DNA polymorphisms. The primer combinations that were polymorphic between parents and pools with contrasting resistance (Fig. 2a) were analyzed individually for each genotype (Fig. 2b) to validate the connection between the TDF and the defense response.

\section{TDF cloning and sequencing}

To recover the polymorphic bands from the polyacrylamide gel, each TDF was marked in resistant parents and $\mathrm{F}_{2}$ plants, rehydrated, removed from the plate, and macerated in $40 \mu \mathrm{L}$ of $1 \times$ TE buffer, according D'Alessio and Gerard (1988). A new PCR was performed with $5 \mu \mathrm{L}$ of this template solution using the same concentrations of reagents as for the selective
Fig. 2 Polymorphisms between resistant and susceptible plants, parent, and $\mathrm{F}_{2}$ generation, indicated by the arrows for the ECTA/EACG primer combination. a Pooling and polymorphism selection. b Confirmation of polymorphism by the decomposition of pools in individual PCRs a

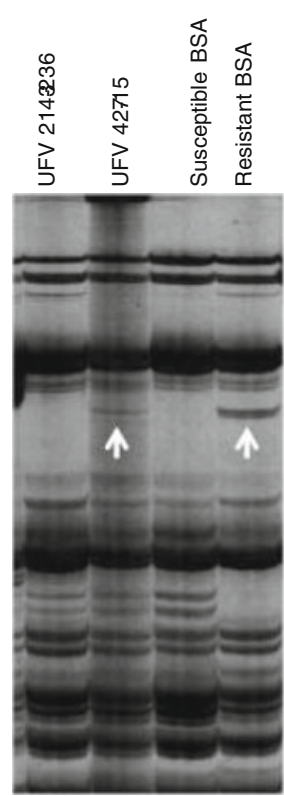

b

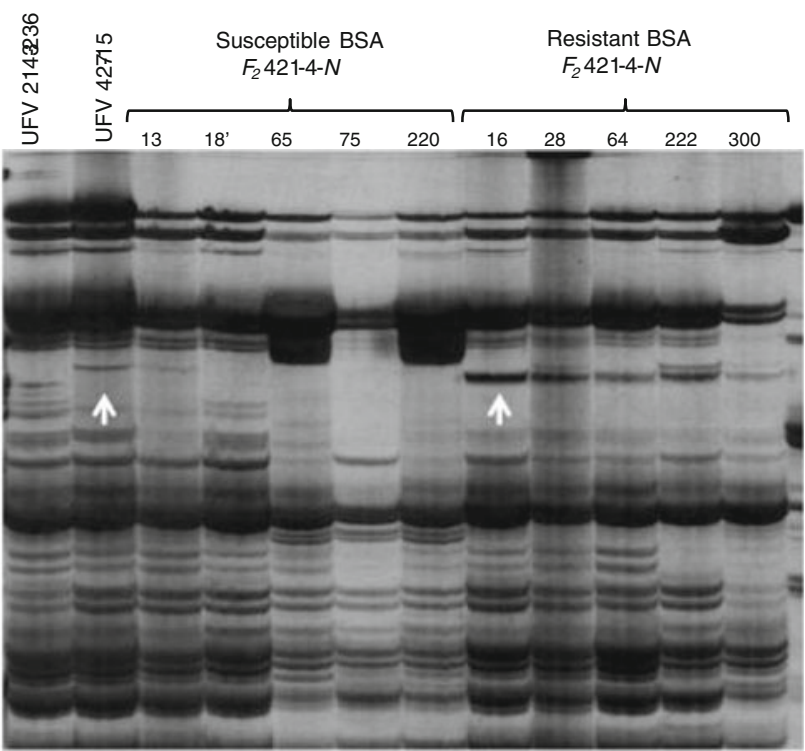


amplification of cDNA-AFLP in a final volume of $50 \mu \mathrm{L}$ and using a program of 32 cycles of $94^{\circ} \mathrm{C}$ for $30 \mathrm{~s}, 58^{\circ} \mathrm{C}$ for $30 \mathrm{~s}$, and $72{ }^{\circ} \mathrm{C}$ for $60 \mathrm{~s}$. The PCR product was separated by $1 \%$ agarose gel electrophoresis at $70 \mathrm{~V}$ for $25 \mathrm{~min}$. The band was excised from the gel and purified using the Illustra GFX ${ }^{\mathrm{TM}}$ PCR DNA and Gel Band Purification Kit (GE Healthcare, NY, USA). After this process, $16 \mathrm{ng}$ of the purified DNA fragment was used for ligation into the pGEM-T ${ }^{\circledR}$ plasmid following the manufacturer's instructions (Promega). E. coli DH5 $\alpha$-competent cells were transformed by thermal shock, and plasmid DNA was extracted using the alkaline lysis method (Clemson and Kelly 2003). Sequencing was performed on a MegaBACE ABI PRISM 1000 sequencer (GE Healthcare).

\section{TDF evaluation of similarity}

A similarity comparison was performed using the National Center for Biotechnology Information (NCBI) (www.ncbi. org) and the Brazilian Coffee Genome Project (Projeto Brasileiro do Genoma Café-https://alanine.cenargen. embrapa.br/coffEST) databases and the BLASTn and BLASTx programs (Altschul et al. 1990). Comparisons were made between the degrees of similarity of the TDF nucleotide sequences and the genes and ESTs. Sequences that had an $E$ value $>1.10^{-5}$ were considered to have no significant similarity. Functions, species of origin, and NCBI accession numbers were assigned to each TDF.

\section{Differential analysis of TDFs by real-time PCR}

Only sequences that were similar to genes linked to the signaling and activation pathways of the defense response were selected. Specific primers for 21 TDFs were obtained using the Primer-BLAST program (http://www.ncbi.nlm. nih.gov/tools/primer-blast/index.cgi), with sizes of 20 bases and melting temperatures of approximately $56{ }^{\circ} \mathrm{C}$. These primers produced amplicons with sizes between 80 and 140base pairs. All primers (Table 1) were used in primerspecific reactions at a final concentration of $5 \mu \mathrm{M}$ for each primer. PCRs with final volumes of $20 \mu \mathrm{L}$ each consisted of $1 \times$ Taq polymerase buffer (High-Fidelity PCR Buffer), 3 . $0 \mathrm{mM}$ of $\mathrm{MgCl}_{2}, 25 \mu \mathrm{M}$ of dNTPs, $0.04 \mu \mathrm{L}$ of ROX, $0.08 \mu \mathrm{L}$ of BSA, $2.0 \mu \mathrm{L}$ of $1: 10,000$ diluted SYBR Green, and $0.25 \mathrm{U}$ of Platinum Taq DNA polymerase (all reagents are from Invitrogen). Four technical replicates and four biological replicates (two for parents and blocks) were analyzed for each treatment (resistant and susceptible). Quantitative realtime PCR was performed in a Step One Plus thermocycler (Applied Biosystems, Foster City, CA, USA). Primer validation was obtained using a relative standard curve with three technical replicates of resistant genotype samples at $48 \mathrm{~h}$ after inoculation in 1:5 serial dilutions at four concentrations starting from the cDNA reaction (diluted one, five, 25, and 125 times). Each reaction used $0.28 \mu \mathrm{L}$ of the cDNA synthesis solution. The PCR program was $90^{\circ} \mathrm{C}$ for $5 \mathrm{~min}$, followed by 40 cycles of $95^{\circ} \mathrm{C}$ for $15 \mathrm{~s}, 60^{\circ} \mathrm{C}$ for $1 \mathrm{~min}$ for the amplification stage, and a cycle of $60^{\circ} \mathrm{C}+0.3{ }^{\circ} \mathrm{C}$ every $20 \mathrm{~s}$ until $95^{\circ} \mathrm{C}$ was reached for the dissociation curve. Primer sets with amplification efficiencies above 0.95 were accepted. The following three constitutive genes were used as reference genes: Ca Ubi (ubiquitin), Ca Tub ( $\alpha$-tubulin exon 2 ), and $\mathrm{Ca}$ actin (actin), as reference was estimated as the average between them, according to Minimum Information for Publication of Quantitative Real-Time PCR Experiments (MIQE) Guidelines (Bustin et al. 2010). Relative quantification cycle $(\mathrm{Cq})$ was calculated by the comparative cycle threshold $\left(\Delta \Delta C_{\mathrm{T}}\right)$ method on the Step One Plus thermocycler using the values of $\Delta \Delta C_{T}$ program and the same cycle program used for the relative standard curve. The experimental design consisted of analyzing the resistant and susceptible genotypes in two biological replicates (parents and blocks) at $0,12,24,48$, and $72 \mathrm{~h}$ after inoculation, with four homogeneous technical replicates. Step One Plus software version 2.0 (Applied Biosystems) was used to analyze the data according to Ali-Benali et al. (2005). The errors relating to the technique concerning the homogeneity of the four technical replicates within each biological sample were tested by Bartlett's test $(p<0.05)$ using the $C_{\mathrm{T}}$ values. The level of expression $(R)$ was calculated by the following formula: $R=2^{-\Delta \Delta \mathrm{Ct}}$, where ${ }^{-\Delta \Delta \mathrm{Ct}}=\left(\Delta C_{\mathrm{T}}\right.$ of target $)-\left(\Delta C_{\mathrm{T}}\right.$ of endogenous gene). Samples from resistant genotypes at time $0 \mathrm{~h}$ were used for comparison (Nicot et al. 2005).

For the quantitative comparison $\left(R_{\mathrm{q}}\right)$ between genes and genotypes, the relative expression based in data $C_{\mathrm{q}}$ were evaluated by a one-way analysis of variance (ANOVA), and the means were compared using Duncan's test $(p<0.05)$.

To isolate differentially expressed genes or groups according to the coexpression of all genes in contrasting genotypes, a Spearman's correlation analysis was performed to compare the intensities of temporal gene expressions with each other, within the same genotype, and between genotypes. The statistical analyses were performed using the STATISTICA 8.0 program (StatSoft ${ }^{\circledR}$ 2009).

\section{Results}

Characterization of resistance to coffee leaf rust

Twenty-four days postinoculation, $H$. vastatrix uredinospores were detected on the leaves of susceptible genotypes but not on resistant genotypes (Fig. 1). The ratio of resistant to susceptible genotypes was 3:1 (Mendelian character), indicating that one gene is involved in the resistance of the HT to pathotype of race II of $H$. vastatrix. 
Table 1 Primers used for the amplification of selected TDF sequences in the quantitative study of gene expression associated with resistance to coffee leaf rust

\begin{tabular}{|c|c|c|c|c|}
\hline Primer (Ca TDF) & GenBank accession & Amplicon (bp) & Sense sequence $\left(5^{\prime} \rightarrow 3^{\prime}\right)$ & Antisense sequence $\left(5^{\prime} \rightarrow 3^{\prime}\right)$ \\
\hline $1 \mathrm{POX}$ & GT029982.1 & 80 & ACGATACCCAAGCGGAACTC & CCTGGTATCCCTGTACCTGTC \\
\hline $2 \mathrm{RGH} 1 \mathrm{~A}$ & GT029983.1 & 107 & CGTCAAGCTCGCTTTGCTCA & TTTGTGCAGCTCGCCGAAAG \\
\hline $14 \mathrm{GR}$ & GT029995.1 & 108 & CGCATGGTATGGTAGCGTCG & ATCCAGGGTCGAGAGCTTGC \\
\hline $19 \mathrm{MEK} 2$ & GT030000.1 & 115 & CCGTGACGTCGACAACCCTA & TGGATCCCTTGAGCAGAGCC \\
\hline 24 СуP450 & GT030005.1 & 107 & ACATCGTGGCAAGAAGGCAA & CGACTGGAAGCTGCCCAATG \\
\hline $41 \mathrm{UbiE} 2$ & GT030022.1 & 95 & GCGGCCTAACAAAATGCTGC & ATTACAGGCCAACACCAGGC \\
\hline 44 PR5 & GT030025.1 & 94 & GCACCCTGCCCCATTTATGC & GTGCCGATGGATTTCAGCCC \\
\hline 48 RLK & GT030029.1 & 121 & CCATCGGTATTTTGCGCGAC & TGCTGGACCCTCGTAGCTTG \\
\hline 53 Begr1 & GT030034.1 & 98 & ACGACAAGGTATCAGCCGGG & GTCGCGCAAAATACCGATGG \\
\hline 54 Pto-like & GT030035.1 & 129 & ATGCCGCGGTAAACTTCGTG & CTGCTTAGCCTGCCCAAAGC \\
\hline $56 \mathrm{SAMsI}$ & GT030037.1 & 95 & CTCTGGTCAAGCCCCCTCAG & AAAGTGGTTCAGCGCACACC \\
\hline 58 MAPK3 & GT030039.1 & 127 & TACGTCAGGCACACTCCCAC & GATCAATGGCCACGGGATGG \\
\hline $61 \mathrm{SAG} 12$ & GT030042.1 & 117 & TCGCTGTTTGCCGGTTTCTG & GCATCGTAGGAAACACGCCC \\
\hline 74 ERB2 & GT030055.1 & 110 & AGCGGAGGGACTCGATATGC & GCTTCCGGTCCTACCCTTCC \\
\hline 77 NBS-LRR & GT030058.1 & 88 & CCAGTGGCTAATGCTCTGCC & TGGACCAGCGTGCATCATCT \\
\hline 81 MAPK2 & GT030062.1 & 112 & TGGGAGGGTCCAGCCAATTC & GCGACTTACGGTGTTGGAGG \\
\hline $87 \mathrm{CDPK}$ & GT030068.1 & 129 & AGGAGTGGGTATGTTGGCACA & TCCCTTGAACAGCAACGCAAC \\
\hline $89 \mathrm{CBP}$ & GT030070.1 & 95 & TACGGCGTATTCACCGGTCC & GCAAGGGAATGAGGGTTGCG \\
\hline 90 Aco1 & GT030071.1 & 83 & AGCAAAGGGACATTCAGCGA & TTCCTAACCGTGTTGCTGGC \\
\hline 98GPX4 & GT030078.1 & 100 & TCCCTGGTGGCATTCCCTTC & TTCGGCCTTAAAGCGTGTGC \\
\hline 99 bZIP56 & GT030080.1 & 86 & TTCGCTTTGTGGCGGACCTA & TCCTGCCGAAGACTGAGAGC \\
\hline Ca-Actin & FJ426886 & 95 & CTTGAAATACCCCATTGAGC & ACAGGATGTTCTTCTGGAGC \\
\hline Ca- $\alpha$-tubulin & AF363630.1 & 128 & TTTGGGCTTCAGATTAGCAC & GCATTCATAACCAACACCCT \\
\hline Ca-ubiquitin & AF297089.1 & 85 & CAAAGGCTCATCTATGCTGG & GATGAAGAACAGAACCACCC \\
\hline
\end{tabular}

$P O X$ peroxidase, $R G H 1 A$ resistance gene analogs $1 \mathrm{~A}, G R$ glutathione reductase, $M E K 2$ mitogen-activated protein kinase $2, C y P 450$ cytochrome $\mathrm{P}$ 450, UbiE2 ubiquitin-conjugating enzyme E2, PR5 pathogenesis-related thaumatin-like protein, Bgerl beta-glucan elicitor receptor, Pto-like Pto R protein kinase-like, $S A M S L S$-adenosyl-L-methionine synthetase-like, MAPK3 mitogen-activated protein kinase 3, $S A G 12$ senescence-associated gene 12-cysteine type peptidase, ERB2 ethylene-responsive element binding protein 2, NBS-LRR nucleotide binding site-leucine-rich repeats, $M A P K 2$ mitogen-activated protein kinase 2, $C D P K$ calcium-dependent protein kinase 5, $C B P$ calmodulin-binding protein, Acol ACC oxidase ACO1, GPX4 glutathione peroxidase, bZIP56 transcription factor bZIP56

Major gene ontology classes associated with resistance

Using the cDNA-AFLP technique combined with BSA, 512 selective primer combinations, 256 of each EcoRI GNN/EcoRI TNN and EcoRI CNN/EcoRI ANN were analyzed; these combinations generated 33,685 amplified transcript-derived fragments (TDFs) in several sequencing gels (data not shown). On average, 66 amplicons were generated by each primer combination, and the sizes of the amplicons ranged between 100 and $2,300 \mathrm{bp}$. A total of 1,380 polymorphic amplicons were identified. However, only 489 amplicons were present in only the parent and resistant group (BSA resistant), and 362 of these amplicons were selected for validation based in at least a band intensity five times stronger in all member (Fig. 2), where the expression of these genes were tested in each individual of the two groups (BSA resistant, and BSA susceptible). Among these amplicons, only 108 were confirmed as differential
TDFs associated to resistance. From these TDFs, 62 were obtained from the EcoRI GNN/EcoRI TNN primer combination, and 46 were obtained from the EcoRI CNN/EcoRI ANN primer combination. The average size of these selected TDFs was approximately 500 bp.

By performing sequence similarity comparisons of TDFs using BLASTn and BLASTx (www.ncbi.gov), 93 sequences from the NCBI database were identified as similar and 15 were not similar to genes deposited in GenBank. The sequences were recorded and entered into the GenBank EST database with consecutive GenBank accession numbers (see http:// www.ncbi.nlm.nih.gov/dbEST/: GT029982 to GT030089). The gene ontology performed using similarity analysis from the functional characterization (Fig. 3) showed that defense genes represent $\sim 22 \%$ of the sequenced TDFs (24 genes), while signaling pathway genes behave $\sim 20 \%$ (21 genes) of the sequenced TDFs. 


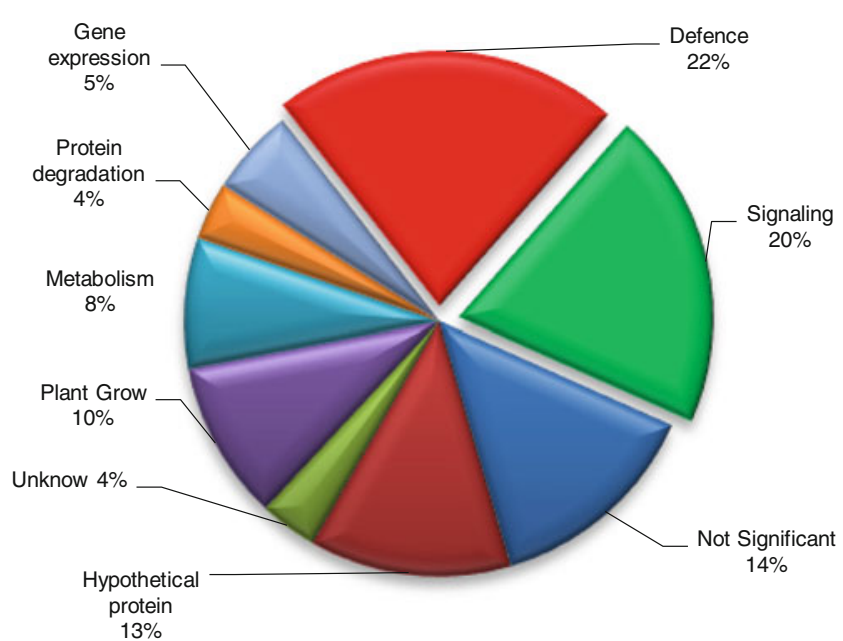

Fig. 3 Putative comparative classification according to the biological function of genes expressed by TDFs with sequences entered into databases, based on the similarity of known sequences detected by queries using BLASTn. (White and Kerlavage 1996)

Validation of cDNA-AFLP/BSA results with gene expression analysis using real-time PCR

We have selected 21 of the 93 genes with high homology to know genes (Table 1). The housekeeping primers have good stability in the presence of these biotic stress and experimental procedure used ( $M$ value of 0.1243 , estimated by geNorm-http://medgen.ugent.be/ judesomp/genorm/). The highest level of expression of genes related to transcription factors and genes responsible for signaling and pathogen recognition was at $24 \mathrm{~h}$ after inoculation (Fig. 4). In this class, genes that were more expressed were $N B S-L R R, R G H 1 A$, and $M E K$, with approximately $12.0,9.3$, and 8.6 times. Among the genes that signal pathogen infection, the NBS-LRR gene was expressed by the resistant genotype (Fig. 4) 4.82 times more. Not less interesting was the response of the kinases MEK, MAPK2, and CDPK with higher differential induction (2.49-, 4.27-, and 5.44-fold, respectively, in resistant genotypes). Between transcription factors, the TDF that encoded $\beta$-Zip showed a significant difference among the contrasting genotypes (4.5-fold more expressed). As a group, the genes that had differential expression related to defense response were more expressed at $72 \mathrm{~h}$ after inoculation. The defense response genes showed no significant changes in expression between resistant and susceptible genotypes, except the protein pathogenesisrelated gene encoding (Traumatin-like, class III) at 17.4 fold compared to control and 5.31 times compared to susceptible and resistant genotypes (Fig. 4).

Temporal profile of gene induction after infection

Correlation analysis (Supplement 1) of the expression transcriptional pattern of the 21 genes in the relation to gene coexpression in time and intensity allowed us to classify the genes in three different classes ( $p$ value between 0.1 and 0.01 ). Class I includes the transcriptional factors EREB1 and bZIP which induction modulation was similar, having a transient increase of expression between 12 and $24 \mathrm{~h}$. The second class include several resistance genes (NBS-LRR, RGH1A, RLK, Berg1, and Pto-like), kinases homologs (MEK, MAPK3, MAPK2, and CDPK), and signaling protein calmodulinbinding protein (CBP), all included in the signaling gene group. $N B S-L R R$ has the highest induction rate in this group and a clear peak of gene expression at $24 \mathrm{~h}$, which is also similar to the other receptor genes of this group. The third group is composed mainly of defense response proteins and pathogenesis-related proteins including the PR5, a higher induced gene in this work. This last class has a peak of gene expression at $72 \mathrm{~h}$ or more. The genes of this group coexpressed between themselves but not with other groups. Positive correlations were observed between defense response genes and signaling genes, but these correlations were not strong (Supplement 1).

\section{Discussion}

In coffee leaf rust incompatible interaction, our genetic analysis has proven that just one gene is involved, making this interaction ideal to identify and to study a specific group of defense associated with coffee resistance to leaf rust race II pathotype. This pathogen is one of the most ancient rust lineages (Grasso et al. 2006). As an example, in coffee rustincompatible interactions, hypersensitive reaction can occur as early as at the appressorial stage, making this a unique feature among rusts (Silva et al. 2008). As a consequence, resistance of coffee involve some plant strategies as old as the rust does, making this system one important research field to be explored to better understand coevolution of rust-host genomes.

CDNA-AFLP coupled to BSA analysis reduces the presence of false positives

In this study, the combined techniques were applied to characterize the expression of 33,685 gene fragments in two parental genotypes and in two sets of five individuals each of susceptible and resistant plants (resistant and susceptible BSAs). With this wide analysis, 1,380 different expressed fragments were identified but only 108 differently expressed genes were confirmed as linked to resistance (close to $1.4 \%$ of the polymorphic fragments). This notable reduction of detection of false positives confirms the advantage of combining cDNA-AFLB with BSA analysis, where not only detection of differentially expressed genes are performed but also more importantly, consistently differentially expressed in different individuals of a segregating population. This strategy has been rarely used, but also has been proved to be efficient in other 
Fig. 4 Qualitative analysis of activation and gene expression in coffee plant resistance to pathotype of race II of $H$. vastatrix. Maximum intensities of expression in resistant genotypes, showing genes from the resistance response signaling pathway and transcription factors at $24 \mathrm{~h}$ after inoculation and defense genes at $72 \mathrm{~h}$ after inoculation (susceptible genotype without significant differences). Significant differences in the relative expression levels of genes were measured by one-way ANOVA with Duncan's mean separation test at 0.05 probability. Between genes (one asterisk) and gene expression between genotypes (two asterisks)

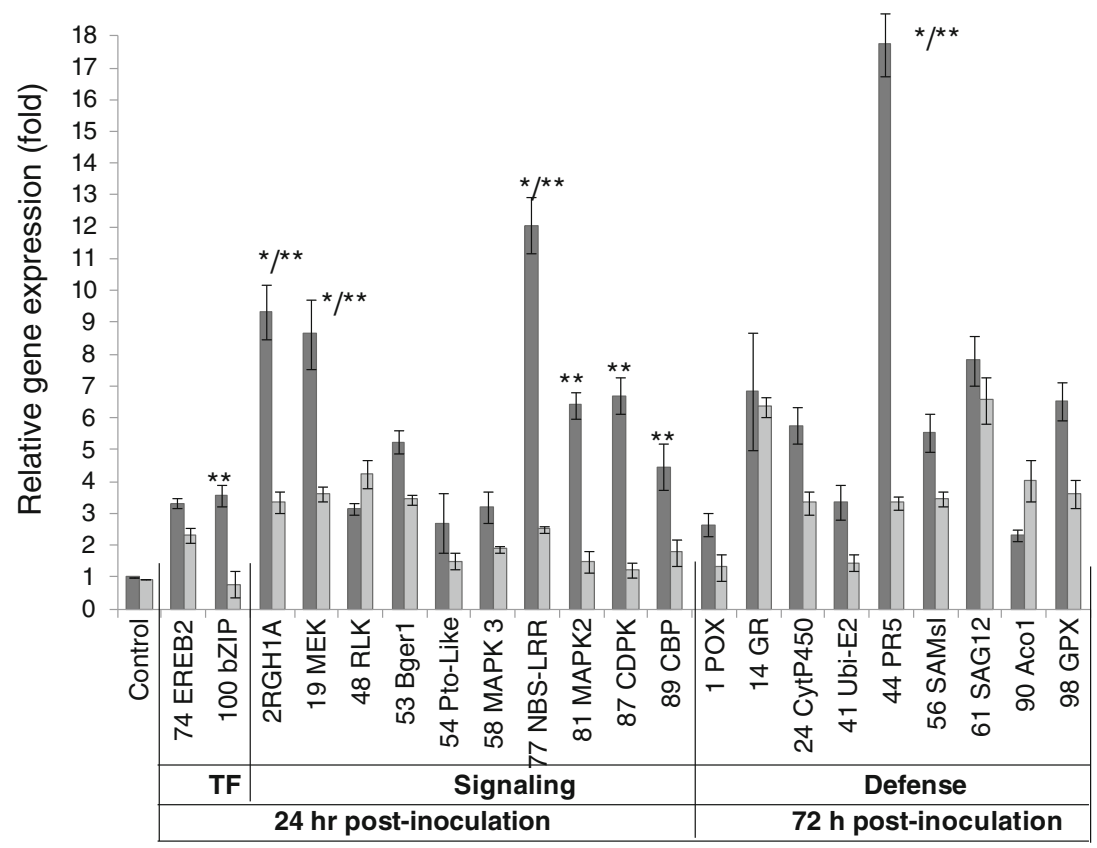

studies of other plant-pathogen interactions (Guo et al. 2006). The low cost and simplicity of this strategy make more advantageous the use of cDNA-AFLP to study transcriptional changes in gene expression when characterized and segregating population of contrasted parents for the desired trait are available.

A new set of coffee leaf rust resistance signaling genes are identified

We complement the study of Guzzo et al. (2009), which has sequenced genes differentially expressed ( $\mathrm{SSH}$ method) in the incompatible interaction using HT and race II spores in libraries done with RNA extracted $72 \mathrm{~h}$ after infection. These results did not overlap our data, since we have used another HT genotype, originating from segregating plants from seeds harvested in Timor Island brought directly to the UFV coffee germplasm bank. The genotype used here is that which has a single dominant resistant gene to race II, whereas the HTCIFC 832/1 has five different resistance genes. Another important difference is that we have analyzed differential expression not restricted to $72 \mathrm{~h}$, but using pooled samples collected 48 and $72 \mathrm{~h}$ postinoculation. Between genes analyzed in the cited work, $22 \%$ were grouped as resistance mechanism (56 genes) and $30 \%$ were grouped as cell maintenance and development (12 genes), but only four genes were confirmed by real-time PCR. The use of BSA represents a second confirmation verifying that 108 resistance-specific associated genes (Fig. 2) have at an least expression five times higher in all five different resistant plants (as exemplified in Fig. 2b). Furthermore, 21 genes were confirmed by real time. The genes reported here are different from those described by
Guzzo et al. (2009) and Diniz et al. (2012). Our work data added to the results of the two other citations raising the interesting result of the involvement of two different resistance genes ( $85 \%$ nucleotide identity) and several transcription factors and kinases. Whether the functions of these genes are dependent of each other will be very important to explore. Arabidopsis could be used to analyze the function of heterologous disease-resistant genes (Azinheira et al 2010; Cheng et al 2013), and interfamily transfer of NB-LRR genes confers resistance to other pathogens (Narusaka et al 2013a, b), since coffee transformation has low efficiency. This recent discovery suggests that whereas the R-genes are highly genotype specific, downstream components of R-genes are highly conserved between different plant species (Narusaka et al. 2013a, b). Otherwise, rapid transient overexpression or antisense of these genes in coffee (Ribas et al 2011) is also an interesting strategy to elucidate more detailed data about the signaling network involved in disease resistance. Ramiro et al. (2010) have identified several WRKY transcription factors. Subtraction methods (our work, Guzzo et al. 2009) were both unable to find any WRKY transcription factors using these different subtraction methods, which suggest that this transcription factors could be more important in basal responses, like nonhost resistance. Temporal profiling and correlational analysis clearly distinguish different patterns for signaling and defense genes.

The rust fungi that develop their hyphae normally activate the defense responses $12 \mathrm{~h}$ after infection in coffee trees (Azinheira et al. 2010; Vieira et al 2012). Ganesh et al. (2006) and Vieira et al. (2012) have studied morphophysiological cellular changes and found that pathogen recognition occurs moments after fungal penetration. At this initial period after infection, nonhost resistance genes are 
mainly expressed. Host resistance genes are expressed later and recognize race-specific pathogen effectors. This response only occurs after the pathogen have survived several successively induced basal plant defenses (Uma et al 2011). Our selection of differential expressed genes has focused on genes expressed at 48 and $72 \mathrm{~h}$ after infection. However, all signaling genes characterized (nine genes, except the Pto-like Rgene) have a peak of gene expression at $24 \mathrm{~h}$ after infection. Curiously, the higher expressed gene was a NBS-LRR gene, which was 14 times more expressed in the resistant genotype than in the susceptible one, and was the second highest induced gene in HdT genotype. The NBS-LRR gene described by Guzzo et al. (2009) was more expressed at $48 \mathrm{~h}$ in other incompatible interactions with coffee leaf rust, and it is possible that this latter induced R-gene acts downstream of the gene characterized here. Alternatively, since other incompatible interaction is described, other specific R-gene expressed at $24 \mathrm{~h}$ at HT-CIFC 832/1 will act upstream of the R-gene described by Guzzo et al. (2009). Considering that other three resistant genes (2RGHA1, Bergl, and Pto-like) are also induced, but at a lower level (no more than $50 \%$ of the induction observed for the NBS-LRR), these differences and temporal profile suggest that this gene could be a good candidate for a single resistant gene that our genetic analysis has identified (Brito et al. 2010; Diola et al. 2011). The differential expression of just one gene from this class is responsible for triggering the activation of resistance responses in barley (Rostoks et al. 2004), sugarcane (You-Xiong et al. 2008), and poplar (Zhang et al. 2008).

Azinheira et al. (2010), also studying resistance against $H$. vaxtratris race II, a prehaustorial rust resistance, and using Arabidopsis thaliana as a model system of heterologous gene for the molecular dissection of coffee responses to leaf rust indicate triggering of the induction of a set of defense-related enzymes peaking at 18 and $42 \mathrm{~h}$ postinoculation. Altogether, we can suggest that the host race-specific-induced recognition event occurs before $48 \mathrm{~h}$, probably between 18 and $24 \mathrm{~h}$. Before this period, defense responses probably are nonhost resistance. A correlation analysis of all temporal profiles reinforces the observation that almost all signaling genes studied have a higher expression at $24 \mathrm{~h}$ and are probably coregulating. Between then, there are four R-genes and five kinases (e.g., MEK, RLK, 2MAPKs, and CDPK), which have between two- to sevenfold higher expression than in an compatible interaction, induction similar to the values reported by Asai and Yoshioka (2008) and Diniz et al. (2012), and which are important resistance signaling elements of plant resistance (Jalali et al. 2006; Zhao and Qi 2008).

A corelational analysis separates defense genes as a separate group of signaling genes. During these processes, groups of genes undergo simultaneous and interdependent activation and are coexpressed in time and intensity similarly in resistant plants (Jia et al. 2000; Trinchieri 2003). This pattern of gene expression in resistant genotypes revealed coexpression during the period of infection, suggesting that the genes may be involved in signaling and defense response pathways. Almost all of these defense genes (seven of nine) have a latter peak of gene expression, which occurs at 48 and/or $72 \mathrm{~h}$. The signaling genes identified here could modulate this late expression pattern, suggesting an increase in the expression of these genes. Between these seven genes, we have mainly antioxidative enzymes, and the protein related to pathogenesis PR5 thraumatin-like of the chitinase group showed the highest relative expression among all analyzed genes. PR-5 proteins are enzymes (chitinases) that hydrolyze chitin, a $\beta$-1,4-linked polymer of $N$-acetylglucosamine (Vasconcelos et al. 2011). The PR proteins, PR-5, are potent antifungal proteins, and higher expression of PR could be a mechanism that contributes to resistance (Vasavirama and Kirti 2012). Because chitin constitutes a large fraction of the cell wall of certain classes of phytopathogenic fungi, these enzymes have been suggested to potentially play a role in defense against these plant pathogens (Li et al. 2010) by causing cell collapse and fungus death (Guzzo et al. 2009; Vasconcelos et al. 2011).

The robustness of the use of cDNA-AFLP coupled to BSA analysis of an incompatible interaction involving a single gene have showed to be sensible enough to isolate good candidates for the single resistant gene and associated signaling pathway elements. The temporal compartmentalization of identified signaling and defense genes and the early expression of signaling genes support the hypothesis that higher expression of the signaling components upregulates the defense genes and that this increased gene expression is associated with a single monogenic resistance to leaf coffee rust disease in the incompatible interaction characterized here. Our high density map of this single resistance gene (Diola et al 2011) have allowed us the identification of three overlapped bacterial artificial chromosomes in this HT genotype, one of them where the NBSLRR-77 is localized, and, together with data presented here, make this gene a good candidate for a resistance gene. The complete new set of 108 resistance-associated genes to race II of $H$. vastatrix could be an important tool to analyze gene expression in other coffee rust-incompatible interactions in order to dissect the mechanism of resistance to coffee leaf rust, an emergent new thread to global coffee production nowadays.

Acknowledgments Thanks to BioCafé (Laboratório de Biotecnologia do Cafeeiro) and to Dr. Eunize Maciel Zambolim for providing the plant material, the $H$. vastatrix isolate, and the physical infrastructure needed for phenotyping. This work is supported by Consórcio Brasileiro de Pesquisa e Desenvolvimento do Café, CNPq, CAPES and Fapemig.

\section{References}

Ali-Benali MA, Alary R, Joudrier P, Gautier MF (2005) Comparative expression of five Lea genes during wheat seed development and 
in response to abiotic stresses by real-time quantitative RT-PCR. Biochem Biophys Acta 1730:56-65

Altschul SF, Gish W, Miller W, Myers EW, Lipman DJ (1990) Basic local alignment search tool. J Mol Biol 215:403-410

Asai S, Yoshioka H (2008) The role of radical burst via MAPK signaling in plant immunity. Plant Signal Behav 3:920-922

Azinheira HG, Silva MC, Talhinhas P, Medeira C, Maia I, Petitot A, Fernandez D (2010) Non-host resistance responses of Arabidopsis thaliana to the coffee leaf rust fungus (Hemileia vastatrix). Ann Bot 88:621-629

Bachem CWB, Van der Hoeven RS, Bruijin SM, Vreugdenhil D, Zabeau M, Visser RGF (1996) Visualization of differential gene expression using a novel method of RNA fingerprinting based on AFLP: analysis of gene expression during tuber development. Plant $\mathrm{J}$ 9:745-753

Bettencourt AJ, Lopes J, Palma S (1992) Factores genéticos que condicionam a resistência às raças de Hemileia vastatrix Berk. et $\mathrm{Br}$. dos clones-tipos dos grupos 1, 2 e 3 de derivados de Híbrido de Timor. Brotéria. Genética XIII(LXXX):185-194

Bettencourt AJ, Rodrigues CJ Jr (1988) Principles and practice of coffee breeding for resistance to rust and other disease. In: Clarke RJ, Macrae R (eds) Coffee. Agronomy, vol 4. Elsevier, London, pp 199-234

Brito GG, Caixeta ET, Gallina AP, Zambolim EM, Zambolim L, Diola V, Loureiro ME (2010) Inheritance of coffee leaf rust resistance and identification of AFLP markers linked to the resistance gene. Euphytica 1:1-14

Bustin SA, Beaulieu J, Huggett J, Jaggi R, Kibenge F, Olsvik P, Penning L, Toegel S (2010) MIQE precis: practical implementation of minimum standard guidelines for fluorescence-based quantitative real time PCR experiments. BMC Mol Biol 11:74

Cabral PGC, Zambolim EM, Zambolim L, Lelis TP, Capucho AS, Caixeta ET (2009) Identification of a new race of Hemileia vastatrix in Brazil. Australas Plant Dis Notes 4:129-130

Capucho AS, Caixeta ET, Zambolim EM, Zambolim L (2009) Herança da resistência do Híbrido de Timor UFV 443-03 à ferrugem-docafeeiro. Pesquisa Agropecuária Brasileira 44:276-282

Cardoso RML (1986) Novas raças de Hemileia vastatrix Berk. et Berk. no Brasil, métodos de identificação, e detecção de grupos fisiológicos em cafeeiros derivados do Hibrido de Timor. Magister Scientiae. Fitopatologia, Universidade Federal de Viçosa, Viçosa-MG. 1986

Cheng Y, Zhang H, Yao J, Han Q, Wang X, Huang L, Kang Z (2013) Cytological and molecular characterization of non-host resistance in Arabidopsis thaliana against wheat stripe rust. Plant Physiol Biochem 62:11-18

Clemson M, Kelly WJ (2003) Optimizing alkaline lysis for DNA plasmid recovery. Biotechnol Appl Biochem 37:235-244

Cressy D (2013) Coffee rust regains foothold. researchers marshal technology in bid to thwart fungal outbreak in Central America. Nature 493:587

D'Alessio JM, Gerard GF (1988) Second-strand cDNA synthesis with $E$. coli DNA polymerase I and RNase $\mathrm{H}$ : the fate of information at the mRNA 5 ' terminus and the effect of $E$. coli DNA ligase. Nucleic Acid Res 16:1999-2014

Diola V, Brito GG, Caixeta ET, Zambolin EM, Sakiyama NS, Loureiro ME (2011) High-density genetic mapping for coffee leaf rust resistance. Tree Genetics \& Genomes. 1-10 DOI 10.1007/s11295-011-0406-2

Diniz I, Talhinhas P, Azinheira HG, Várzea V, Medeira C, Maia I, Petitot AS, Nicole M, Fernandez D, Silva MC (2012) Cellular and molecular analyses of coffee resistance to Hemileia vastatrix and nonhost resistance to Uromyces vignae in the resistance-donor genotype HDT832/2. Eur J Plant Pathol 133:141-157

Duplessis S, Joly DJ, Dodds PN (2011) Rust effectors. In: Martin F, Kamoun S (eds) Effectors in plant microbes interactions. WileyBlackwell, Oxford, pp 157-195. doi:10.1002/9781119949138.ch7

Ganesh D, Petitot AS, Silva MC, Alary R, Lecouls AC, Fernandez D (2006) Monitoring of the early molecular resistance responses of coffee (Coffea arabica L.) to the rust fungus (Hemileia vastatrix) using real-time quantitative RT-PCR. Plant Sci 170:1045-1051

Grasso V, Sierotzki H, Garibaldi A, Gisi U (2006) Relatedness among agronomically important rusts based on mitochondrial cytochrome b gene and ribosomal ITS sequences. J Phytopathol 154:110 118

Guzzo SD, Harakava R, Tsai SM (2009) Identification of coffee gene expressed during systemic acquired resistance and incompatible interaction with Hemileia vastatrix. J Phytopathol 161:1-14

Guo J, Jiang RHY, Kamphuis LG, Govers FA (2006) cDNA-AFLP based strategy to identify transcripts associated with avirulence in Phytophthora infestans. Fungal Genet Biol 43:111-123

Jalali BL, Bhargava S, Kamble A (2006) Signal transduction and transcriptional regulation of plant defence responses. J Phytopathol 154(2):65-74

Jia Y, McAdams SA, Bryan GT, Hershey HP, Valent B (2000) Direct interaction of resistance gene and avirulence gene products confers rice blast resistance. Embol J 19:4004-4014

Leng X, Xiao B, Wang S, Gui Y, Wang Y, Lu X, Xie J, Li Y, Fan L (2010) Identification of NBS-type resistance gene homologs in tobacco genome. Plant Mol Biol Rep 28:152-161

Li DM, Staehelin C, Wang WT, Peng SL (2010) Molecular cloning and characterization of a chitinase-homologous gene from Mikania micrantha infected by Cuscuta campestris. Plant Mol Biol Rep 28(1):90-101

Narusaka M, Kubo Y, Hatakeyama K, Imamura J, Ezura H, Nanasato Y, Tabei Y, Takano Y, Shirasu K, Narusaka Y (2013a) Breaking restricted taxonomic functionality by dual resistance genes. Plant Signal Behav 21(6):8, Epub ahead of print

Narusaka M, Kubo Y, Hatakeyama K, Imamura J, Ezura H, Nanasato Y, Tabei Y, Takano Y, Shirasu K, Narusaka Y (2013b) Interfamily transfer of dual NB-LRR genes confers resistance to multiple pathogens. PLoS One 8(2):e55954. doi:10.1371/journal.pone. 0055954, Epub 2013 Feb 20

Nicot N, Hausman J, Hoffmann L, Evers D (2005) Housekeeping gene selection for real-time RT-PCR normalization in potato during biotic and abiotic stress. J Exp Bot 421:2907-2914

Nishimura MT, Dangl JL (2010) Arabidopsis and the plant immune system. Plant J 61:1053-1066

Noir S, Combes MC, Anthony F, Lashermes P (2001) Origin, diversity and evolution of NBS-type disease-resistance gene homologues in coffee trees (Coffea L.). Mol Genet Genom 265(4):654-662

Prakash NS, Marques DV, Varzea VMP, Silva MC, Combes MC, Lashermes P (2004) Introgression molecular analysis of a leaf rust resistance gene from Coffea liberica into Coffea arabica $\mathrm{L}$. Theor Appl Genet 109:1311-1317

Prakash, N., Bhat, S. S., Hanumantha, B. T., Várzea, V. M. P.,Marques, D., Silva, M. C. \& Jayarama (2010). Break down of rust resistance in some HdT introductions and its derivatives in India-new challenges for Arabica coffee breeding in the light of increasing pathogen virulence. (Poster presented at the 23 rd International Conference on Coffee Science (ASIC), 3-8 October 2010, Bali.)

Ramiro D, Jalloul A, Petitot AS, Maluf M, Fernandez D (2010) Identification of coffee WRKY transcription factor genes and expression profiling in resistance responses to pathogens. Tree Genet Genomes 6:767-781

Ribas AF, Dechamp E, Champion A, Bertrand B, Combes MC, Verdeil JL, Lapeyre F, Lashermes P, Etienne H (2011) Agrobacteriummediated genetic transformation of Coffea arabica (L.) is greatly enhanced by using established embryogenic callus cultures. BMC Plant Biol 19:11-92

Rodrigues CJ, Bettencourt AJ, Rijo L (1975) Races of the pathogen and resistance to coffee rust. Annu Rev Phytopathol 13:49-70

Rostoks N, Steffenson BJ, Kleinhofs A (2004) Structure and expression of the barley stem rust resistance gene Rpg1 messenger RNA. Physiol Mol Plant Pathol 2:91-101 
Silva MC, Guerra-Guimarães L, Loureiro A, Nicole MR (2008) Involvement of peroxidases in the coffee resistance to orange rust (Hemileia vastatrix). Physiol Mol Plant Pathol 72:29-38

Silva MC, Várzea V, Guimarães LG, Azinheira HG, Fernandez D, Petitot AS, Bertrand B, Lashermes P, Nicole M (2006) Coffee resistance to the main diseases: leaf rust and coffee berry disease. Braz J Plant Physiol 18(1):119-147

StatSoft ${ }^{\circledR}$ (2009) STATISTICA 8.0 Software Version Trail. https://www. statsoft.com/secure/statistica8trial.html. Accessed June 2009

Trinchieri G (2003) Interleukin-12 and the regulation of innate resistance and adaptive immunity. Nat Rev Immunol 3:133-146

Uma B, Rani TS, Podile AR (2011) Warriors at the gate that never sleep: non-host resistance in plants. J Plant Physiol 168(18):2141-2152

Várzea VMP, Marques DV (2005) Population variability of Hemileia vastatrix vs coffee durable resistance. In: Zambolim L, Zambolim E, Várzea VMP (eds) Durable resistance to coffee leaf rust. UFV Press, Viçosa-Brazil, pp 53-74

Vasavirama K, Kirti P (2012) Increased resistance to late leaf spot disease in transgenic peanut using a combination of PR genes. $\mathrm{J}$ Funct Integr Genom 12:1-10

Vasconcelos EAR, Santana CG, Godoy CV, Seixas CDS et al (2011) A new chitinase-like xylanase inhibitor protein (XIP) from coffee (Coffea arabica) affects Soybean Asian rust (Phakopsora pachyrhizi) spore germination. BMC Biotechnol 11:14-21
Vieira A, Talhinhas P, Loureiro A, Thürich J, Duplessis S, Fernandez D, Silva MC, Paulo OS, Azinheira EG (2012) Expression profiling of genes involved in the biotrophic colonisation of Coffea arabica leaves by Hemileia vastatrix. Eur J Plant Pathol 133:261-277

White O, Kerlavage AR (1996) TDB: new databases for biological discovery. Methods Enzymol 266:27-40

Yao YX, Li M, Li Z, Hao YJ, Zhai H (2007) A novel gene, screened by cDNA-AFLP approach, contributes to lowering the acidity of fruit in apple. Plant Physiol Biochem 45:139-145

You-Xiong Q, Jian-Wei L, Ji-Sen Z, Miao-Hong R, Li-Ping X, MuQing Z (2008) Molecular cloning and characterization of a nonTIR-NBS-LRR type disease resistance gene analogue from sugarcane. Sugar Technol 10:71-73

Zambolim L, do Vale FXR, Costa H, Pereira AA, Chaves GM (2002) Epidemiologia e controle integrado da ferrugem-do-cafeeiro. In: Zambolim L (ed.), O estado da arte de tecnologias na producão de café. Viçosa- MG, Brasil. In: O estado da arte de tecnologias na producão de café. Viçosa- MG, Brasil, UFV., pp 369-450

Zhang Q, Zhang Z, Lin SZ, Zheng HQ, Lin HY, An XM, Li Y, Li HX (2008) Characterization of resistance gene analogs with a nucleotide binding site isolated from a triploid white poplar. Plant Biol 3:310-322

Zhao S, Qi X (2008) Signaling in plant disease resistance and symbiosis. J Integr Plant Biol 50(7):799-807 